\title{
Progress in community policing
}

\author{
Alexis A. Aronowitz'
}

The development of community-based policing

This article examines the development of community-based policing in the United States and the Netherlands. These two countries were selected because the United States has been the forerunner of research into the police and one of the first countries to attempt to introduce on a wide-scale, and conduct research into community policing. In the Netherlands, the Major Cities Policy, a governmental approach to addressing the cities' problems provided an interesting basis for comparison. Policy or operational changes in the police organization are generally influenced by the political climate and or scientific research. Both of these factors played a major role in the US. This section begins with a brief historical view of the factors which brought about changes within American policing, ultimately resulting in a new concept of community policing. This is followed by developments which led to community policing or the concept of the 'neighbourhood teams' (wijkbureaus) in the Netherlands.

\section{Development in the United States}

The American police are 'decentralised' resulting in some 17,000 local and state agencies with 'departments' comprising fewer than five officers (Samaha, 1994) while New York City in 1992, for example, boasted a department with over 27,154 officers (Bureau of Justice Statistics, 1993, p. 47). This diversity has resulted in different policies, guidelines and operational procedures being employed and tested in various police departments.

American policing, if one can talk about the police as a single entity, has, since its inception, undergone numerous reorganizations, both in terms of operating procedures as well as the philosophy guiding the departments. From the beginning of American policing in the late 1700s and through the mid-1880s,

\footnotetext{
1 The author is a post-doc researcher at the International Police Institute Twente (IPIT) at the University of Twente. She would like to thank professor G.J.N. Bruinsma for suggestions and critical comments on this paper.
} 
the police were organized locally and maintained allegiance to the local municipalities (Greene, 1993). ${ }^{2}$ As a branch of the government, it also had to be prevented from intruding too deeply into the affairs of the American public, thus the police role was to 'react' to public calls rather than to take any proactive role in the community. The police at this time were more likely to be seen as 'extensions of corrupt politicians' or criminals rather than as members of the community (Haller, 1976). Police corruption, it was thought, could best be solved by removing officers from the corrupting influences, the public. In the late 1800 s and early 1900 s the police became a bureaucracy organized along paramilitary lines. This was done to professionalise the forces as well as to shift allegiance to the organization and chain of command (and thus away from the corrupting influences of politicians and the public). This 'era of professionalism' introduced positive changes into the organization, setting standards and uniformity in police procedures and practices (Greene, 1993). Challenges to police legitimacy brought on by the turbulent 1960s (the Civil Rights Movement, anti-Vietnam protests, urban unrest), public mistrust and dissatisfaction, and hefty criticism forced the police to once again examine their relationship with the public and their operating procedures. What followed was a barrage of research pertaining to the police.

Perhaps most disturbing (and at the same time enlightening) in the USA were studies in the 1970s indicating that police were ineffective in preventing (Kelling, 1974) and detectives were ineffective in solving crimes (Greenwood et al., 1977) and that rapid response to calls from the public had little effect on solving crimes (Kansas City, Missouri Police Department, 1977; Spelman and Brown, 1984). In other words, whatever the police had been doing up to that point had had very little effect on crime. 'Whereas the police of the past were simply corrupt, modern-day police, as known at that time, were also inefficient and ineffective' (Greene, 1993, p. 77).

A new concept in the form of team-policing was introduced in the 1970s. With an emphasis upon strengthening the relationship between the public and the police, this philosophy introduced decentralization to improve service delivery and permanent geographical assignment. Despite its tremendous potential for change and the ardour with which it was initially received, power struggles and jealousy within police departments prevented the idea from finding solid footing.

Foot patrol programmes were then introduced. These served to bring officers out of their cars and into closer contact with the public. They increased public

2 The American constitution and political system founded on the premise of protecting the citizen against an intrusive national government, is paralleled in the development of the police forces. 
perception of safety and improved police-community relations. They also served as a predecessor to the current community-policing models.

\section{Development in the Netherlands}

The development of proactive, neighbourhood-based policing in the Netherlands followed similar patterns as in the United States. In the 1950s and 1960s emphasis was on law enforcement and crime fighting (emphasising preventive patrol in automobiles, rapid response to calls from the public and investigation after a crime was committed). The prominence of the crime-fighting model led to the expansion of the role of investigation in the 1960s and 1970s (Horn, 1993). The 1960s were also characterised as a turbulent time in the Netherlands. Riots, demonstrations, strikes and illegal squatters, and the manner in which the police responded to these incidents also called into question the legitimacy of the police (as well as the government). In addition to social unrest, crime rates began rising dramatically in the late $1960 \mathrm{~s}$ as well (Kroes et al., 1994; Stichting Maatschappij en Politie, 1995).

In 1977 the Project Group Organizational Structures (Projectgroep Organisatiestructuren) - comprised of a group of young police officers published a report 'Police in Transition' (Politie in verandering) in which they advocated that police services should be provided in small geographically decentralized units with a relatively large degree of independence. The police should be tasked with providing all police services in that area. Furthermore, the police should strive toward integration into and a good working relationship with the community (Horn, 1993). As a result of recommendations by this group, the neighbourhood team (wijkteam) model was introduced in some police forces in the Netherlands.

The concept of community policing, first seen in the form of a 'wijk' or neighbourhood agent, was introduced into the city of Haarlem, soon followed by Amsterdam and other cities (Horn, 1993; Van der Vijver, 1990). The neighbourhood police concept aimed at bringing more police officers on the street, establishing small police stations in the neighbourhood, and removing the strict separation between patrol officers and detectives (Horn and Koolhaas, 1990).

Until the beginning of the 1980s the Dutch government believed that fighting crime by taking a hard line approach was not only unnecessary, but it would further criminalize offenders (Cachet and Van der Torre, 1994). This approach was abandoned by the mid-1980s when the Commission Roethof ${ }^{3}$ recognised

3 The Commission Roethof, named after its chairman, was a parliamentary commission appointed to formulate a new criminal policy to address the increase of 'minor' offences in the Netherlands. 
that minor offences and disturbances were impacting negatively upon the quality of life in the neighbourhoods. The Commission Roethof called for more (and more forceful) police and criminal justice intervention.

The criminal political agenda called for a three-step approach to reduce and prevent crime (Cachet and Van der Torre, 1994, p. 302): 1 increase functional supervision by hiring watchmen, security guards and more personnel in stores: 2 reduce the opportunity to commit crime with an emphasis upon 'technoprevention'; 3 take measures to strengthen the integration of youths into society. This resulted in a myriad of programmes and measures implemented by the police, justice agencies, municipal services and organizations of individuals all at the local level.

Changes in the police role in the Netherlands could be seen at this time as well. As in the US, the Dutch police shifted from a predominantly reactive force to a more responsive, localised organization. In the beginning of the 1990s the focus of the police forces was on organized crime. Specialized and predominantly centralized units (divisions) of detectives were further expanded and police forces lost interest in community policing. At the same time, the policy was that all police officers in local stations could handle all police activities. except the surveillance of organized crime groups.

Recently, community policing has once again become prevalent due to the fact that national and local politicians have demanded more police officers on the streets in order to reduce the public's feelings of insecurity in their neighbourhoods. The Dutch police. along with other municipal and justice agencies were given an impetus in the form of the Major Cities Policy (discussed later in this article). An integral approach is the new philosophy guiding the Dutch police in which the police work together with relevant partners in handling social problems in the local area. The Public Prosecution department has been (in some cities) or will soon be established in the neighbourhoods as well to enhance the integral approach (see Boutellier in this volume).

\section{Some parallels between the United States and the Netherlands}

The problems, and the necessity of finding another solution to the problems took a parallel course in both countries. Both countries were facing rising crime rates amid social unrest in the 1960s. In both countries the police authority was being challenged and the effectiveness questioned by the citizenry. Even the police organizations, based on empirical research, had begun to question the effectiveness of what they had previously done: respond

\footnotetext{
Techno-prevention emphasises technical instruments such as alarms, radios and video cameras to reduce or prevent crime.
} 
(or 'react') to incoming calls and preventive patrol. This, coupled with the realization that the police could not be effective in preventing or solving crime without the input and support from the community, led the police in both countries to search for new means to approach the problem.

A reorganization occurred in both countries emphasising a relatively autonomous, decentralized unit addressing the problems of a small and geographically stable area. This, coupled with the notion of the need for increased community contact, interaction and joint problem-solving came to be known as community policing.

Despite many parallels between the two countries, there are stark differences. Community policing began as a philosophy and organizational movement within police departments in the United States. In contrast, the Major Cities Policy which encouraged, even demanded an integrated approach, i.e. the police, public, justice and municipal agencies working together to address the community's problems, was given an impetus from the municipal and central governments in the Netherlands. This policy will be described more in-depth later on.

\section{Community policing and the changing role of the police}

To fully appreciate the monumentality of this shift in philosophy and behaviour (from traditional to community policing) it is important to understand the elements in 'traditional' policing. Traditional policing, still employed in many jurisdictions throughout the United States, and to a lesser degree in the Netherlands, is characterised by a reactive force with an emphasis upon crime control and public order. For years, separated from the public by a police culture which viewed the public as 'them' as opposed to 'us' (the police), and plagued by problems surrounding race relations, police-community contact was held to a minimum. Patrolling was done in cars, which themselves created an automatic barrier between the police and the public (Wilson and Kelling, 1982).

Emphasis upon technology and crime control is easy to understand in light of increasing crime rates in the United States during that time. Cries were made for more police officers on the street. Emphasis was placed upon preventive patrol and rapid response time as means of reducing crime.

Research in the US found, however, that increased (random) patrol had little effect upon the actual crime rate (Kelling, 1974) and that rapid response time to calls for assistance rarely resulted in arrest (Trojanowicz, 1988). ${ }^{5}$ Further-

5 This is often due to the fact that there is a time lapse between the committal of the crime and the point in time when the crime is discovered or that victims wait a substantial time before calling the police. Despite a rapid police response, the perpetrator is long gone. 
more, research in the US conducted by the Bureau of Justice Statistics showed that less than 10 per cent of a patrol officer's time is spent on crime related activities (Bureau of Justice Statistics, 1993).

Much of this holds true for the Netherlands as well. In the Netherlands few police officers were busy specifically with fighting crime (Stichting Maaatschappij en Politie, 1995). And Cachet and Van der Torre (1994) argue that more officers on the street does not necessarily lead to an increase in safety. This does not mean, however, that whatever the police do is useless in controlling crime.

\section{A shift in philosophy}

In 1969 a Stanford university psychologist, Zimbardo, conducted experiments with 'abandoned' cars in various neighbourhoods (in the Bronx, a lower class borough in New York City and in Palo Alto, California). With license plates removed and the hood up, the car was vandalised in the Bronx within 10 minutes of its abandonment. Within 24 hours the car had been stripped and afterwards randomly destroyed. In the relatively well kept neighbourhood in Palo Alto the car remained untouched for a week until Zimbardo took a sledgehammer to the car. Within a few hours the car had been totally destroyed (Wilson and Kelling, 1982). Wilson and Kelling refer to this as the 'broken windows theory'. Once one window is broken it is simply a matter of time before more vandalism and destruction follow. They argue that 'at the community level, disorder and crime are usually inextricably linked, in a kind of developmental sequence' (1982, p. 281).

Once a breakdown in community ties is evidenced and a 'no-one-cares' attitude encroaches, vandalism will occur possibly preceding the perpetration of more serious crimes. Fear generated by disorder and incivility (panhandlers, drunks, drug addicts, gangs of youths hanging out on the street) are of as much, if not more importance in determining peoples' perception of crime and insecurity. Wilson and Kelling argue that once neighbourhoods are touched by disorder (the panhandler, who represents the first broken window), non-serious offences followed by more serious crimes are likely to occur. Therefore, if we are to reduce or prevent crime, it is necessary to reduce disorder as well. Experiments were conducted with police foot patrol as a means of reducing crime.

Research on the Newark, New Jersey Foot Patrol programme showed that citizens fear crime as well as disorder. Results of the project indicated that crime rates did not go down but people felt safer in their neighbourhoods. What in essence happened is that foot patrol officers, through increased interaction with the public were more effective in restoring and maintaining 
order which led citizens to believe that their city streets were safer. ${ }^{6}$ Perhaps then, the most effective approach to reducing disorder and preventing crime would be to increase police-community contact and address problems before they began or escalated (pro-active policing) rather than waiting for a call to respond in a patrol car (reactive policing).

\section{Community and problem-oriented policing}

Two somewhat overlapping philosophies have gained credibility in the United States. They are community policing and problem-oriented policing. While some see problem-oriented policing as an integral part of community policing (Bureau of Justice Assistance, 1994), others see it as a distinct philosophy and operational method (Gramckow and Jacoby, 1993). Much has been written about community policing in the United States. Despite the fact that since the early eighties the merits of community policing have been debated and argued and programmes have been experimented with and employed, there is still little consensus concerning what community policing really is, or exactly what a department must do if it wants to introduce the concept (Bureau of Justice Assistance, 1994).

Trojanowicz and Carter (1988, p. 10) provide the following definition: 'Community policing, a philosophy and not a specific tactic, 'is a proactive, decentralised approach, designed to reduce crime, disorder, and by extension, fear of crime, by intensely involving the same officer in the same community on a long-term basis, so that residents will develop trust to co-operate with police by providing information and assistance to achieve those three crucial goals." 7 One of the elements which differentiates community policing from other more traditional forms of policing is that the community is instrumental in determining (or helping to determine) police priorities. The Clark County Sheriff's Office (1997) takes the definition one step further: 'Community Policing is a philosophy, management style, and organisational strategy that promotes pro-active problem solving and police-community partnerships to address the causes of crime and fear as well as other community issues. This definition adds the important element of police-community partnerships to address the problem, placing the burden of problem-identification and solving on the community as well as the police.

In essence then, despite differences in operational patterns, all community

6 A by-product of the foot Patrol program is that citizens had a more favourable opinion of the police than did citizens living in other areas and police officers in the Foot Patrol program reported greater job satisfaction, higher morale, and a more positive opinion of the citizens in their neighbourhoods than did ofticers patrolling in cars (Wilson and Kelling, 1982).

7 Quote from J. Eck, W. Spelman et al. Cited in Bureau of Justice Assistance, 1994, p. 21. 
policing programmes should incorporate the following two elements (Gramckow and Jacoby, 1993, p. 28; Bureau of Justice Assistance, 1994): community partnership and problem solving: they should establish strong links between police and communities to co-ordinate law enforcement with other services affecting the neighbourhood's quality of life (Community Partnership); and they should increase the ability of law enforcement to identify, analyze, and respond to community problems in systematic ways (Problem Solving).

The second philosophy, problem-oriented policing, first proposed by Goldstein (1979), relies less on community participation and more on the problemsolving abilities of the police. In this operational model, police identify persistent problems, the source of these problems and possible solutions. Problem solving is based on the assumption that 'crime and disorder can be reduced in small geographic areas by carefully studying the characteristics of problems in the area, and then applying the appropriate resources'. For problem solving to be most effective, however, the police must have an indepth knowledge of the community. This almost automatically demands a close working relationship with the citizens to help identify problems. What does all this mean to the police officer? The change has required that officers move from patrol cars to foot patrol, bicycles or, as in some cities, in-line skates in order to be more accessible to the public. The officer must now think in broader terms: instead of only enforcing the legal code, the officer must evaluate a situation and seek a possible solution, in other words a shift from the notion of crime repression to crime prevention. In addition to an increased interaction with citizens in the community or neighbourhood the officer must serve as a regulating mechanism with the purpose of stimulating the public to solve their own problems. The individual police officer as well as the entire department must begin to reassess police performance which will require a shift from an incident-driven (solving a burglary) to a problemsolving approach (increasing feelings of security).

\section{The use of informal justice}

'Justice' is usually served when an appropriate sentence is handed down for a particular offence. This is done by the judge (the sentence in the Netherlands is requested by the Public Prosecutor). Justice may, however, be interpreted in a different way. Justice is also applied by police officers in handling particular incidents based upon the specifics of the case, those involved and circumstances surrounding the event.

Police officers can not arrest every law-violator for every transgression of the law (the criminal justice system is incapable of processing all offenders) 
therefore the police exercise discretion in arresting or employing alternative measures. Even in Germany, where the principle of legality requires police officers to arrest in all criminal offences, Feltes (1993) found that German police exercise some form of 'informal discretionary power'. This practice, while more limited than in the United States, is also exercised by police officers in the Netherlands (Van der Vijver, 1997).

While the exercise of discretion has often been linked in the United States with police abuse of power directed at minorities, this does not have to be the case. Studies of discretion and decision-making among police show that 'even when the police are called, as often as not they decide to deal with crime through mechanisms other than the criminal law institution' (Ericson et al., 1993, p. 50). Even in the Netherlands the police often handle situations involving ongoing conflict (domestic disputes or those between neighbours) in which criminal offences may have occurred (assault) with measures other than arrest: advising, mediation, referral (Stichting Maatschappij en Politie, 1995). If alternative measures are applied in the best interest and to the satisfaction of the victim, suspect and the community, this can be interpreted as a means of applying justice.

According to Van der Vijver (1997), the work that patrol officers do is not influenced by policy-oriented principles; their work involves dealing with problems and the attempt to find solutions that are dependant upon the context of the situation. In order to 'solve' these problems and prevent further escalation (from a domestic argument to domestic violence - and hence a crime) the police officer must look for the most appropriate solution - and that is not always formal arrest. How then does the officer determine what is best under the circumstances for a given suspect, victim and community? An intimate knowledge of the community's mores, values, concerns, and problems will provide the officer with some indication of appropriate steps to take in a given situation. This intimate knowledge can be gained through the practice of community policing, foot patrol and increased community contact. Exercising informal justice requires, however, not just knowledge about the community's concerns, but also alternatives available in the community. Case in point: homeless drug addicts have begun harassing citizens and causing disturbances at night creating fear in the community. Citizens have complained to the police about the problem. The officer has a number of options. (S) he can either reprimand the addicts and ask them to move to another (nonresidential) location, the addicts can be brought into the station and detained for disturbing the peace, or the officer may contact a drug rehabilitation centre and shelter seeking assistance for the persons concerned. The third option will have the most long-term effect and benefits both addicts and residents. It also, however, requires the co-operation of social welfare and health services which 
depend greatly upon financial support from the municipal government. Problem solving in this sense cannot and will not be effective without the cooperative venture of municipal governments and other social welfare organizations. By the same token, children skipping school can either be dealt with harshly and punished, or aiternative solutions (achieved with input from the children, their parents, the police and the schools) can be found. This searching for the most appropriate solution in a given situation is a form of justice. Problem-solving is limited only by imagination, creativity, and available options in the community. The police can not be expected to provide all of the services but should function as 'knowledge brokers' in collaboration with other social institutions' (Ericson et al., 1993, p. 50). An important aspect of community policing is to stimulate the public to look for solutions to their problems without calling the police. An integrated co-operative approach with both criminal justice agencies (the prosecution department, the courts, parole, child welfare services) as well as social service agencies (departments of health, welfare, social services, public sanitation department) is necessary to ensure that problems will be addressed seeking the most appropriate solutions.

\section{Recent developments in the Netherlands}

The path towards 'community policing' or rather the concept of shared responsibility was given an impetus by the central government. The Second Chamber of Parliament in 1993 published the findings concerning the general picture of 'unsafe' conditions in the Netherlands in it's Integral Safety Report (Integrale Veiligheidsrapportage; Tweede Kamer, 1992-1993, 23 096, nrs. 1-2). The central government recognised the necessity to improve security in the cities and address the problems of crime and the community's fear of crime and unsafe conditions. This resulted in the present central government, aided by the mayors of the four largest cities, formulating a policy, ${ }^{8}$ known as the Major Cities Policy (Grote-Stedenbeleid) and entering into a formal covenant with a number of cities in the Netherlands. What began in July 1995 with the four largest cities, Amsterdam, Rotterdam, the Hague and Utrecht, has now expanded to include more than 21 other cities. This plan aimed at providing an integrated, neighbourhood-based approach to social problems, both in terms of the co-operative relationship between central and municipal governments, as well as between judicial and social agencies, businesses, neighbour-

A A centrally-designed, widespread integrated approach was not unique in the Netherlands. The previous government had introduced a plan similar to the Major Cities Policy under the name 'Social Renewal' (Van der Wouden, 1995). 
hood groups and individuals within the cities. Input from citizens is an integral part of the policy. Improving the cities requires addressing the problems of high unemployment, low salaries, poor social integration, low educational levels and high crime rates and feelings of insecurity.

To improve the quality of life in the cities a policy was developed encompassing five general areas: employment, education, care, the quality of life, and public security and safety. The covenant provides a number of intended results or goals for the cities in each of these five areas. Within the sector of public safety the four major areas of concentration are: youth, drugs, supervision and the police, and neighbourhood safety plans. Citizen responsibility is particularly evident in the neighbourhood plans (and the neighbourhood safety plans). Citizen involvement was encouraged from the initial stage, in identifying problem areas in their communities, through the operational stage. The police were instrumental in collaboration with citizens in the formulation of neighbourhood safety plans. The central government's role was limited to providing financial support and guidance to the cities. The actual problemsolving was to occur at the municipal, district and even neighbourhood level. The philosophy behind the Major Cities Policy is that of integral safety. An integrated approach to tackling the cities' problems incorporated the concepts of joint partnerships between the local police, the Public Prosecution department, various government agencies and citizens groups and of attacking the problems from multiple angles resulting in the improvement of education and employment opportunities, the creation of jobs and the promotion of community involvement. The covenant, for instance, called for creating new jobs under the '40,000-jobs plan' for long-term unemployed and training them to function as city and public transportation watchmen which would reduce unemployment and create safer conditions in the city. This, in turn would have an impact on the crime rate, which would influence peoples' perceptions of their safety, which would ultimately improve the quality of life in the cities. A midterm review of the Major Cities Policy ${ }^{9}$ indicates that the cities are fulfilling their obligations and that numerous programmes have been developed and implemented. Justice organizations have become more involved in the community and representatives from agencies interviewed in almost all four cities reported an improved working relationship with other agencies and the municipal government. Numerous respondents reported the police task as having changed and improved, as a direct result of the Major Cities Policy. The police in all four cities are currently involved in expanding their approach from a repressive one to one more focused on pro-active intervention, preven-

9 This research was conducted in the cities of Amsterdam, Rotterdam, the Hague and Utrecht by the International Police Institute at the University of Twente (Bruinsma and Aronowitz. 1997). 
tion, care and after-care. As a result of a more expanded role and a deeper involvement at the neighbourhood level, the police have developed a closer relationship with the public. In this new approach the role of the police has changed. The police are no longer solely responsible for safety in the neighbourhoods, but have become partners within a network of co-operating private and public organizations, to include the public. The police have had to adapt their responses and activities (crime fighting and maintaining public order) to other partners. Together they try to divert offenders from the criminal justice system and search for solutions to the problems. The police now use their discretionary power to administer various forms of informal justice: in a given situation the police may prohibit kids from entering certain areas, send them to social or welfare services, let them perform community service, impose a fine on them, and so on. The role of the judge has become less important in this nèw integral approach.

\section{Consequences of community policing}

While community policing is expected to have only positive consequences for the community, it will have both positive and negative consequences for the criminal justice system. This section examines the effect on these two institutions.

\section{Consequences for the community}

The consequences for the community are evident. Police services to the community should improve as citizens become more actively involved in identifying problems. In addition to an improved relationship with the police, citizens are supported and encouraged to look for solutions to their own problems. Rather than relying solely upon the police to solve their problems they begin seeing other agencies (public health, housing authorities, sanitation department) as possible providers of services and problem-solvers. Research in the United States indicates that residents report a reduction in the fear of crime and 'increased confidence and (a) sense of empowerment' (Gramckow and Jacoby, 1993, p. 31).

\section{Consequences for the criminal justice system}

Experience to date has shown mixed; but predominantly positive results in community policing. An initial increase in reported crimes occurs. As relationships improve and citizens become more confident in their police or in the fact that something can be done about their problems, they are more inclined 
to call the police and report crimes that previously went unreported (the dark figure). To acquire a more reliable measure of the crime rate, victimization studies or inquiries of the public should be made. Despite an initial increase in reported crimes, some studies have shown that community policing has aided in reducing crime rates (Pate et al., 1986; Trojanowicz, 1982; Hornick et al., 1989), and in particular, targeted crimes have decreased. ${ }^{10}$

Community policing has had a positive effect on the police officers involved who report more job satisfaction (Gramckow and Jacoby, 1993; Trojanowicz, 1988). Community policing is expected to have a great impact upon other criminal justice agencies as well as the local government. Police will exercise 'informal justice' in more situations and will mete out: warnings, citations, referrals to counselling or other agencies, fines, community service orders. If fewer cases are handled formally by the police and complaints are directed elsewhere, there should be a reduction of cases coming into the criminal justice system. This in turn should lighten the burden but at the same time change the nature and priority of cases filtered through to the public prosecutors office and the court system.

While little research has concentrated on the effect that community policing has had on other agencies (Gramckow and Jacoby, 1993), some logical developments can be expected. At the same time that the burden is decreasing for criminal justice agencies, other social service agencies will experience an increase in the number of calls and demand for services.

\section{Impact upon the judiciary}

Gramckow and Jacoby (1993) report that prosecutors and judges are optimistic about and supportive of community-based policing programmes. It allows closer contact with the public for these agencies which would otherwise have extremely limited contact. This is evidenced in the Netherlands by the introduction of Justice in the Neighbourhood programmes (Justitie in de buurt) which places public prosecutors in the neighbourhoods for the purpose of enhanced contact with the community and local police and provides the community with insight into the workings of these organizations (see Boutellier in this issue). shelters for battered women, educators, ministers and newspaper editors. The police developed a variety of responses to avoid having to arrest the offender(s): referral to counselling. forcing offenders to undergo treatment to avoid jail and obtaining restraining orders. During the time the program was in operation, domestic murders declined considerably. 


\section{Conclusions}

Police departments in both the Netherlands and the United States were forced to do some 'soul searching' in the 1960s and 1970s when faced with social unrest, criticism, rising crime rates and the recognition that current practices were ineffective in reducing crime. When the notion of crime prevention, rather than crime suppression began taking hold, the police were forced to shift from a reactive to a proactive force. This also required increased community contact and joint problem identification and solving. The concept of community policing began to gain in popularity.

Community policing, however, is not without problems and is certainly not a panacea to solving all of the community's ills. There are simply some forms of crime (for example white collar and environmental crime) which can not and will not be prevented by increased communication with and involvement in the community (Kerner, 1993). Thus, there is still a need for repressive and reactive policing and 'crime solving' by detectives. Community police officers can, however, be successful in early intervention to prevent further escalation of 'problems' which may lead to certain criminal offences (neighbourhood or domestic disturbances).

Assuming a police department is successful in introducing the changes and gaining the support of its officers, the problem then becomes, how does one motivate the community? The community is an abstract term which, when used in this sense, gives the impression that we are talking of a singular entity. In fact, most 'problem-ridden' communities are multi-cultural, multi-ethnic, racially mixed, and plagued with diverse problems (poor integration, high unemployment, low socio-economic status). Further complicating the problem is the fact that many minorities have, at best, a strained relationship with the police. How does one win the trust of a suspicious community - particularly when the police have traditionally had a reputation for mishandling certain segments of society. ${ }^{\text {" }}$ Despite its best efforts, community policing will fail without open lines of communication and support of the community the police are assigned to serve. The question then becomes, to what degree must the police attain community support or co-operation in order to guarantee success? Is increased communication sufficient or must the police actively involve residents of the community in specific projects? If so, how does one go about doing this? What may work successfully in one neighbourhood, may fail miserably in another.

"At the time that this article was being written, police officers in a borough in New York City were involved in a vicious attack on a citizen of Haitian background. Three police officers in Amsterdam are under investigation for having manhandled a homeless man resulting in his death. 
With increased community contact and guided by a 'problem solving' (rather than a crime fighting) philosophy, the police have been encouraged and given more leeway to deal informally with cases, in other words, to apply forms of informal justice. In so doing, the police are confronted with an ethical issue. The application of informal justice (or even formal arrest, for that matter) must be done for the benefit of those involved. Any decision to arrest or apply other measures (referral, counselling, etcetera) must not be made based upon the prejudices of individual officers. The most fair and effective approach to solving the problem or handling the situation must be the motivating factor behind the police use of informal justice.

The application of informal justice can be both advantageous as well as dangerous. On the one hand, it should reduce the number of cases entering the formal criminal justice system thereby reducing problems of overload for the prosecution department and the judiciary. If applied correctly, it should result in the most effective disposition, whereby all concerned, including the community, profit. The danger lies in the fact that informal justice is a powerful police tool, as such decisions and actions, remaining out of the formal criminal justice system, are not subject to judicial review. A professional police force armed with sufficient information and proper guidance from partners such as public prosecutors, health and social services and community participants should ensure the proper application of such informal justice decisions. Is community policing the answer to most of our problems? While both practitioners and academicians in the United States are optimistic, the implementation of community policing has, in some instances, met with resistance on the part of the police. Those actually involved in community policing projects, however, report increased job satisfaction and improved community-police contacts. Citizens report increased feelings of safety in their cities. Some projects report a reduction in targeted crimes. In the Netherlands, projects introduced under the auspices of the Major Cities Policy are still too new to evaluate on their success or failure. It does appear that this policy has resulted in an increased neighbourhood involvement on the part of the police. A powerful impetus in terms of financial resources and guidance from the central government as well as active participation by numerous municipal agencies and the citizens is expected to result in improvements in the safety and quality of life in Dutch cities. Whether or not this new integrated, community-police problem-solving approach is successful in reducing crime remains to be seen. If, however, the citizens report increased feelings of security and an improvement in the quality of their neighbourhoods and lives, then it may be said that success has been achieved in at least one area. 


\section{References}

Bruinsma, G.J.N., A.A. Aronowitz

Samen op weg naar meer veiligheid: een tussentijds procesevaluatie van de beleidsuitvoering van het Grotestedenbeleid op het terrein van de veiligheid van Amsterdam, Den Haag, Rotterdam en Utrecht (unpublished report)

Enschede, International Police Institute Twente. 1997

Bureau of Justice Assistance Understanding Community Policing: A Framework for Action

1994 (taken from the Internet at http:// www.ncjrs.org/txtfiles/commp.txt)

Bureau of Justice Statistics

Report to the Nation on Crime and Justice

Washington, DC. US Department of Justice, 1993

\section{Bureau of Justice Statistics}

Sourcebook of Criminal Justice Statistics: 7992

Washington, DC, US Department of Justice, 1993

Cachet, L., E. van der Torre

De hardnekkige mythe van een blik agenten

Tijdschrift voor Criminologie, vol. 36, no.

4, 1994, pp. 30i-315

Clark County Sheriff's Office

Community Oriented Policing

1997 (taken from the internet at http://

www.co.clark.wa.us/sheriff/inter/cop.htm)

Ericson, R.V., K.D. Haggerty, K.D.

Carriere

Community policing as communications policing. In: D. Dölling. T. Feltes (eds.).
Community Policing: Comparative Aspects of Community Oriented Police Work Holzkirchen, Obb., Felix, 1993, pp.41-69 Feltes, $\mathrm{T}$.

Foreword: police research in Germany. In: D. Dölling. T. Feltes (eds.), Community Policing: Comparative Aspects of Community Oriented Police Work

Holzkirchen, Obb., Felix, 1993, pp. 3-7

\section{Goldstein, $\boldsymbol{H}$.}

Improving Policing: A Problem-Oriented

Approach

Crime and Delinquency, vol. 25, no., 1979, pp. 236-58

Gramckow, H., J. Jacoby

Community policing: a model for local governments. In: D. Dölling. T. Feltes (eds.), Community Policing: Comparative Aspects of Community Oriented Police Work

Holzkirchen, Obb., Felix, 1993, pp. 27-39 Greene, J.R.

Community policing in the United States: historical roots, present practices and future requirements. In: D. Dölling, T. Feltes (eds.), Community Policing: Comparative Aspects of Community Oriented Police Work Holzkirchen, Obb., Felix, 1993, pp. 71-91 Greenwood, P.W., J. Chaiken, J. Petersilia

The Criminal Investigation Process Lexington, Heath, 1977

Haller, M.H.

Historical roots of police behaviour:

Chicago, 1890-1925

Law and Society Review, vol. 10, no. 2. 1976. pp. 303-323 
Horn, J.

Probleemgerichte aanpak van onveiligheid

Justitiële Verkenningen, vol. 19, no. 5 , 1993, pp. 24-49

Horn, J., E. Koolhaas

Wijkteampolitie in Nederland

Het tijdschrijft voor de politie, vol. 52, no. 1, 1990, pp. 22-30

Hornick, J.P., B.A. Burrows et al. An Evaluation of the Neighborhood Foot Patrol Program of the Edmonton Police Service

Canadian Research Institute for Law and the Family. 1989

\section{Kansas City, Missouri Police Depart-} ment

Response Time Analysis Reports

Washington. DC, National Institute of Law Enforcement and Criminal Justice, 1977

\section{Kelling, G.L.}

The Kansas City Patrol Experiment Washington, DC, The Police Foundation, 1974

\section{Kerner, H.J.}

Crime prevention and the role of the police: an analytical framework. In: D. Dölling, T. Feltes (eds.), Community Policing: Comparative Aspects of Community Oriented Police Work Holzkirchen, Obb., Felix, 1993, pp. 13-26

Kroes, L., L.L. Meiberg, G.J.N.

\section{Bruinsma}

Vernieuwingen in politiezorg

IPIT nr. 4.

Enschede, International Police Institute

Twente, 1994

Pate, A.M., M.A. Wycoff et al. Reducing Fear of Crime in Houston and Newark
Washington, DC, Police Foundation, 1986

Samaha, $\mathbf{~}$.

Criminal Justice

St. Paul, West Publishers, 1994

Spelman, W., D.K. Brown

Calling the Police: Citizen Reporting of Serious Crime

Washington, DC, National Institute of Justice, 1984

\section{Stichting Maatschappij en Politie} Toekomst gezocht: Het functioneren van de politie ter discussie

Dordrecht. Stichting Maatschappij en Politie, 1995

Trojanowicz, $\mathbf{R}$.

An Evaluation of the Neighborhood Foot Patrol Program in Flint, Michigan

East Lansing, Michigan, School of Criminal Justice, Michigan State University, 1982

Trojanowicz, R.C., D. Carter

The Philosophy and Role of Community

Policing

East Lansing. Michigan, National Center for Community Policing. School of Criminal Justice, Michigan State University, 1988 (taken from the internet http:// www.ssc.msu.edu/ cj/cp/cpphil.html)

\section{Tweede Kamer}

Integrale Veiligheidsrapportage, (19921993) 23 096, no. 1-2

\section{Van der Vijuer, C.D.}

Community policing: een overzicht. In:

C. Eliaerts, E. Enhus, R. Senden (ęds.),

Politie in beweging

Antwerpen/Arnhem, Kluwer, Gouda

Quint, 1990, pp. 17-30

Van der Vijuer, C.D.

Hoofdstukken politiestudies

Enschede, Internationaal Politie Instituut

Twente, 1997 


\section{Van der Wouden, $R$.}

Integraal veiligheidsbeleid tussen

symboliek en bestuurlijke drukte

Justitiële Verkenningen, vol. 21, no. 5.

1995, pp. 49-61

Wilson, J.Q., G.L. Kelling

Broken windows: the police and

neighborhood safety

The Atlantic Monthly, no. 243, 1982. pp.

29-38 